\title{
PEX5-Related Protein
}

National Cancer Institute

\section{Source}

National Cancer Institute. PEX5-Related Protein. NCI Thesaurus. Code C118539.

PEX5-related protein (626 aa, $70 \mathrm{kDa}$ ) is encoded by the human PEX5L gene. This protein plays a role in the localization of hyperpolarization-activated cyclic nucleotidegated channels. 